Int. J. Electrochem. Sci., 12 (2017) $9104-9120$

\title{
Methanol Extract of Slanum Nigrum as Eco-Friendly Corrosion Inhibitor for Zinc in Sodium Chloride Polluted Solutions
}

\author{
Abd El-Aziz S. Fouda ${ }^{1}$, Emad E. El-Katori ${ }^{2, *}$ and Saedah Al-Mhyawi ${ }^{3}$ \\ ${ }^{1}$ Department of Chemistry, Faculty of Science, Mansoura University, El-Mansoura, 35516, Egypt \\ ${ }^{2}$ Department of Chemistry, Faculty of Science (New Valley), Assiut University, El-Kharja, 72511, \\ Egypt. \\ ${ }^{3}$ Department of Chemistry, Faculty of Science-Al-Faisliah, King Abdulaziz University, Jeddah, Saudia \\ Arabia. \\ *E-mail: emad_992002@yahoo.com, emad.elkatori@scinv.au.edu.eg
}

doi: $10.20964 / 2017.10 .64$

Received: 2 June 2017 / Accepted: 8 August 2017 / Published: 12 September 2017

In this work, Slanum Nigrum extract has been tested as eco-friendly green dissolution inhibitor for zinc in $3.5 \% \mathrm{NaCl}$ and $16 \mathrm{ppm} \mathrm{Na}_{2} \mathrm{~S}$ solution by using mass loss, Tafel polarization, electrochemical impedance spectroscopy (EIS) and electrochemical frequency modulation (EFM) techniques. The surface morphology of zinc specimens in absence and presence of Slanum Nigrum extract has been evaluated by SEM and AFM measurements. The obtained results has been illustrated that Slanum Nigrum extract functioned as an effective and good inhibitor. The inhibition efficiency has been found to improve with improvement of extract dose but decreases with improvement in temperature reaching maximum inhibition efficiency $81.5 \%$ at $30^{\circ} \mathrm{C}$ at $500 \mathrm{ppm}$ after $180 \mathrm{~min}$ immersion. Tafel curves illustrated that the polarization discovered that the extract coordination are mixed type and has been followed Langmuir Adsorption isotherm. The adsorption of the extract molecules on zinc metal surface has been agreed with Freundlich and Langmuir adsorption isotherms.

Keywords: Slanum Nigrum, $3.5 \% \mathrm{NaCl}$ and $16 \mathrm{ppm} \mathrm{Na}_{2} \mathrm{~S}$ solution, Zinc corrosion, Mass loss, Tafel Polarization, EIS, EFM, SEM, AFM.

\section{$\underline{\text { FULL TEXT }}$}

(C) 2017 The Authors. Published by ESG (www.electrochemsci.org). This article is an open access article distributed under the terms and conditions of the Creative Commons Attribution license (http://creativecommons.org/licenses/by/4.0/). 